\title{
From Quarantine to Mainstream: The Literary and Historical Journey of American Mixed-Race Heroines
}

\section{Beverly Tomek}
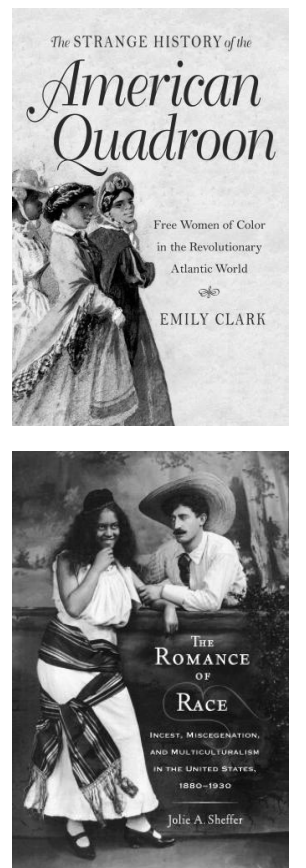

THE STRANGE HISTORY OF THE AMERICAN QUADROON: Free Women of Color in the Revolutionary Atlantic World. By Emily Clark. Chapel Hill: University of North Carolina Press. 2013.

THE ROMANCE OF RACE: Incest, Miscegenation, and Multiculturalism in the United States, 1880-1930. By Jolie A. Sheffer. New Brunswick, NJ: Rutgers University Press. 2013.

Racial "color lines" in the United States and the plight of those who have dared to cross them have long fascinated historians, sociologists, psychologists, novelists, and playwrights alike. In the nation's early years, especially from the period of the Haitian Revolution to the American Civil War, the specter of "racial mixing" threatened the social and political structures in a nation built upon race-based slavery. As abolitionists cried out against slavery, they were met with a fierce resistance. They were accused of supporting "amalgamation," a term that was used as a rallying cry against emancipation. For anti-abolitionists, black freedom would too 


\section{Beverly Tomek}

likely lead to a nation of racial hybrids. Abolitionists responded by pointing out that most of the racial mixing in the nation resulted from the power white men held over enslaved black women on southern plantations, but even many white opponents of slavery admitted to discomfort with the notion of too much intimate contact with African Americans.

During the Civil War, those who opposed black freedom coined the term "miscegenation" and used it to play on existing fears and stir others, in both the North and the South, to resist any new social order based on social equality, claiming that in such conditions blacks and whites would mix freely. This message was loud and clear, and so was the response. The post-Civil War years saw the emergence of Jim Crow segregation and the use of brutal tactics such as lynching to ensure the maintenance of white racial purity. Legal and extralegal means sought to prevent people from crossing the carefully constructed and rigidly maintained racial divide in the U.S. well into the twentieth century. Whether "amalgamation" or "miscegenation," mixing would not be tolerated in mainstream culture. At the same time, however, Americans remained in many ways fascinated with this taboo subject. What of those who dared to cross the lines, or of those born of such unions? ${ }^{1}$

In recent years, scholars of American Studies have begun to examine in depth the history of, and reaction to, love across racial and ethnic lines in the U.S. ${ }^{2}$ Two new works in this field, Emily Clark's The Strange History of the American Quadroon: Free Women of Color in the Revolutionary Atlantic World and Jolie A. Sheffer's The Romance of Race: Incest, Miscegenation, and Multiculturalism in the United States, 1880-1930, collectively illustrate the unique and challenging position of those born of such unions. Focused primarily on history but also incorporating literature, Clark creates a case study to explain the historical origins of New Orleans' reputation as the exotic home of the almost mythical American "quadroon," often portrayed as the "tragic mulatto." Clark's work highlights the "otherness" of the legendary quadroon and the process that left her "colonized" in that city to show how the tragic mulatto became a prominent but very much misunderstood figure in the cultural imagination. Sheffer employs history but relies primarily on literary technique to examine works in the literary genre of "racial romance" as she brings the topic into a later period and shows how mixed-race writers at the turn of the twentieth century built on tales such as that of the tragic mulatto to call for a more inclusive multicultural American society. She explains how writers with firsthand familiarity of that special space between races appropriated the image for their own ends as they tried to open the door for acceptance and equality. While Clark argues that the writers of popular fiction and travel stories helped cordon off the mulatto, Sheffer shows how some tried to set this figure free.

During the course of the nineteenth century, the quadroon became a stock image of New Orleans' culture, with travel narratives describing the women and the unique society they allegedly inhabited. According to these narratives, and the fiction they spawned, this society included special "quadroon balls," 
where black men were excluded and white men were encouraged by the mothers of quadroons to take them as concubines. Such salacious tales led people from across the United States to travel to the city during the antebellum years, taking with them expectations of seeing this iconic figure. Clark's study sets out to investigate not only how this quadroon tourism came to be, but also what was truth and what was fiction in the elaborate stories that circulated about free women of color in New Orleans.

Clark's first task was to ascertain why the quadroon was associated specifically with New Orleans in the popular imagination, when people of mixed parentage lived throughout the U.S. What she uncovered was a fascinating history that took her from Saint-Domingue (Haiti) to Philadelphia before ending in New Orleans. According to Clark, the image of a beautiful mixed-race seductress was an image Americans "deployed in response to racial anxieties magnified by the Haitian Revolution" (5). The women of color who traveled to the U.S. as refugees of that war captured the nation's attention in a way that allowed Americans to focus on their foreign nature and ignore their domestic counterparts, the "homegrown American quadroon" (6). The first of the refugees landed along the Eastern Seaboard, with the main group finding its way to Philadelphia in 1793. Commercial concerns kept many Philadelphians from allying with the refugee cause, and though some in the city offered financial relief, they did not welcome the refugees as neighbors. Some Philadelphians even proposed settling the Haitians in rural New York on land that the Oneida Nation had signed over to the U.S. in a questionable treaty. According to Clark, this scheme contained "more than a hint of quarantine" and foreshadowed the next wave of refugees' colonization in New Orleans (21).

The refugees' presence in the nation's then-capital, a city that was also the home of the American abolition movement, created a complicated situation. To begin with, the young republic was still in its infancy and, some believed, susceptible to the radical ideas of the French and Haitian revolutions. Perhaps the most radical of these ideas involved slavery and racial equality. Even though the Pennsylvania Abolition Society had secured in 1780 a gradual abolition act for their state and was in the process of fighting for an end to slavery nationally, they were not yet prepared for the Haitian model of immediate abolition followed by racial equality. According to Clark, the refugees "modeled in their intimate lives a radical blindness to color that challenged the Philadelphians to contemplate a more revolutionary reordering of established hierarchies than even universal abolition promised" (22). Thus, when free women of color sought refuge in the city, they aroused not only curiosity and fascination but also fear. In Philadelphia, the heart of American politics, the quadroon could only become a symbol of the chaos of the Haitian Revolution and a symbol of hidden truths. She could not stay.

Fortunately for those who found the presence of the Haitians in the nation's then-capital unsettling, the next wave of refugees landed in far-away New Orleans in 1809. It was there that the national imagination transformed the 


\section{Beverly Tomek}

quadroon from a threat to society to a tamed exotic curiosity, mastered for the benefit and pleasure of white men. According to Clark, "In New Orleans, the avatar of Haiti was transformed from a bloodthirsty, rebellious black army into a feminine seductress who submitted willingly to white male control" through a "sleight of hand that preserved the peace of mind of the American slave republic" (38-39).

By 1809, the popular imagination had created the stereotype of the hypersexual mixed-race woman who loved luxury and preferred white men over black, thus robbing white women of the economic security of marriage. Even if this image disturbed some, it bothered people less than the image of black rebellion embodied in the black Haitian man who had risen up out of slavery, fought valiantly for his freedom, and, in many cases, slain his oppressor. While such a man would resist being re-enslaved and, according to popular fear, likely lead slaves in the U.S. in a similar revolt, the woman was "in the end, a woman susceptible to the mastery of any white man who could satisfy her taste for luxury" (53).

While Americans thus expected the free women of color who arrived in New Orleans to be either "pampered concubines of French men" or "unattached women on the make in search of economically advantageous relationships with white men that ran the gamut from long-term cohabitation to prostitution" the women themselves were products of much more complex realities (59). For one matter, the free black Dominguans preferred marriage to men of their own community, but many would not be able to attain this goal because the skewed gender ratio, made worse by adult men of color being denied entry in 1809 by local officials who feared they would lead uprisings, prevented this happy ending for a large portion of the women. As for relations with white men, Americans had misunderstood and misconstrued the system of ménagére, whereby Dominguan women would manage a white bachelor's household. This frequently, but not always, led to a life partnership between the two, but it was not salacious or exotic as the popular imagination would have it. This system died out soon after the refugees' arrival in New Orleans, but it was replaced with a similar system called plaçage, under which a free woman of color, a placée, would play a similar role. Whereas the Dominguan system allowed the woman agency and autonomy, travel narratives and literature described the placée as "dependent and defenseless against the exploitation of her affections by a fickle white lover" (66). This situation, which was key to neutralizing the dangerous Haitian múlatresse, left the New Orleans version of the quadroon less threatening because she was now "fully mastered" (70).

The writers of travel narratives and novels did not confine their distortion to the story of the refugees, but extended their misperceptions to native free women of color in New Orleans, whom they also described as mulatto concubines. Clark takes on both of these misrepresentations and shows that native women, like the refugees, generally preferred marriage to men of their own racial community. She shows that "marriage, not concubinage, was the tradition 
New Orleans free people of color established and perpetuated" and that even girls born to white fathers and mothers of color were more likely to marry black men than white by the 1830s (96). Clark contends that the historical inaccuracies that resulted from the tales of predatory quadroons fed into expectations that women of African descent "were supposed to be hypersexual Jezebels, beings whose libidinous essence inexorably roused white male lust" (96). Importantly, and unfortunately, this trope justified white men's exploitation of women of color.

Another important point Clark makes is that not all cross-racial relationships were salacious or exploitive. She describes many "life partnerships across the color line" that were long lasting and produced families that were as stable as they could be, given circumstances such as laws against "intermarriage" (97). In these relationships, the men generally acknowledged their children officially and within their extended families and incorporated their "unofficial" families into their European kin and social networks (102). At odds with fictional accounts that portrayed men with a closet black mistress and family and a legal white family, Clark found that most of these men remained permanent bachelors since they could not legally marry the women they loved. Beyond the legal handicap, they created as stable and traditional a family as they could, finding ways to "constitute the ideals of patriarchal responsibility and fidelity in a family form that was otherwise fundamentally illicit" (102). All in all, Clark concludes, "the typical experience of a woman of color born free in colonial New Orleans was that of a long-term relationship with a single partner" (103). Due to limited options in the 1820s and 1830s, Haitian refugees and their descendants remained more likely than native women to seek partnerships with unmarried white men, and Clark contends that the quadroon connections described in travel narratives represented an adaptation resulting from their new situation.

The image of the kept and exploited woman of color was just too powerful to ignore, however, especially for abolitionists who built upon it to create the stereotype of the "tragic mulatto." Beginning in the 1830s, abolitionists used the stereotype for their own purposes to illustrate the suffering of black women at the hands of white men. Using a "literary construction of the quadroon," abolitionists and other writers, despite their intent, perpetuated an inaccurate story that essentially robbed women of color of their rightful role as human beings with agency. Whether they meant to or not, writers of tragic mulatto tales perpetuated the notion of separation and otherness. Though their goal was often to illustrate the horrors of slavery, they also "exposed the impossible position of mixed-race people in a society defined by a racial binary" (134). Clark concludes that "literature has locked the quadroon into a powerfully established storyline from which deviation is virtually unimaginable, even for historians" (191). By trying to recover the truth, she hopes to "not only make the past more knowable" but to "make a more just and humane future imaginable" (197). 


\section{Beverly Tomek}

In many ways, Sheffer's books seems to answer Clark's call to find a more accurate past and use it to help shape a more racially inclusive future. By focusing on stories that encompass a broad geographical range and feature a number of different combinations of "races" and ethnicities, Sheffer shows that many authors actually worked to pull the heroines out of the shadows. The main characters of the works she analyzes fight to come out of the margins and assume a central position, not only in the nation's past but also in its future. Clark showed that keeping people of mixed backgrounds "foreign" was central to maintaining control over them, and Sheffer's subjects, quite cognizant of that fact, work to correct the situation by escaping the quarantine Clark described. While Clark maintains that antebellum writers portrayed the quadroon as "the victim of a corrupt culture foreign to American values in the nonslave states," the authors featured in Sheffer's book set out to prove that those of mixed heritage were not foreign at all but instead represented one of the most important characteristics of Americanness - the combination of cultures and ideas that made the nation strong (Clark, 133). For Sheffer's authors, cross-racial and cross-ethnic unity and understanding are the key to making the U.S. progressively stronger and more inclusive. Thus, while the literature of the 1840 s created the tragic mulatto, later literature sought to give her agency and focus on her power rather than her tragedy.

The aim of Sheffer's study is to uncover the radical history of American multiculturalism by examining recurring conventions found in a number of pieces of popular fiction from the turn of the century and tracing the ways in which the authors used their characters to fight against gendered forms of racism. These tales, which were produced roughly a generation after the abolitionist works Clark considered, featured mixed-race protagonists "caught between two cultural "worlds"" and looking for their place in U.S. society (1). Significantly, the stories were produced by writers who were themselves of mixed ethnicity and struggling to make their own way in American culture and to, as Clark suggested, make a more inclusive future imaginable. The tales (some novels, some short stories, and even a museum exhibit) all center around characters of mixed ethnicity - a "mulatto" of black and white American parents in Pauline Hopkins' Of One Blood (1903); "half castes" of Asian and Anglo American parentage in Winnifred Eaton's short stories; "mestizos" of Spanish and Native American heritage in Maria Cristina Mena's stories; a "half-breed" of Native American and Anglo American parentage in Mourning Dove's Cogewea: The Half Blood (1927); and various combinations of southern and eastern European groups in a museum exhibit in Jane Addams' Hull House.

Whereas Clark showed that, at its worst, literature can perpetuate stereotypes that dehumanize the mulatto figure, Sheffer maintains that the fiction she studies does the opposite, giving agency, leadership, and foresight to those of mixed race. She focuses on their active role in navigating U.S. culture and in forcefully pushing for a more inclusive nation. These racial romances, she maintains, provoke "serious reflection over the nation's changing demograph- 
ics and its history of inequality" by revealing "a history of exploitation of racialized women by white men" and offering "a multiracial model of national identity that promises a more egalitarian future for minorities in the United States or those affected by its imperial reach" (2-3). She concludes that because racial romances forced readers to acknowledge the history of racial injustice and "imagine a more egalitarian future," they "helped to change social attitudes over time" (5). Acknowledging that readers have generally focused on the stereotypes in works of this genre, she contends that, when read more carefully and considered beyond the stock images readers immediately recognize, they open "a window to a more radical prehistory of modern multiculturalism than we currently acknowledge" (5).

In all of the stories Sheffer analyzes, authors presented tales of interracial relationships and incest to call attention to the dangers of the nation not recognizing its exploitive past and taking steps to rectify the situation. In one example, Eaton (who wrote under the pen name Onoto Watanna) told the story of an Anglo American man's attraction to a young Asian woman who he later learns is his own daughter. At that point, he is left with the choice of continuing his game and committing incest or acknowledging his paternity. He chooses the latter and, according to Sheffer, allows the "half caste" to claim her whiteness. In the end, "Eaton's stories imply that without clear ties to a single racial or national — and perhaps most important, familial — community," women of mixed background "are at greater risk of being treated as aesthetic and sexual objects by the white men who pursue them" (62). Thus, Eaton's story "A Half Caste" serves to warn readers "that the nation's failure to acknowledge its interracial history (and the inequalities that underlie it) threatens the basic unit of society: the nuclear family" (68). Whether or not readers received Eaton's message, state and federal lawmakers in the U.S. did not take heed. As Clark showed, most of the white fathers of New Orleans' free women of color had tried, like the father in Eaton's story, to share their whiteness by acknowledging their children's paternity, but this did not work out in a society that refused to legally accept mixed unions and open its arms to multi-ethnic offspring. This would remain the case well into the twentieth century. Even so, Sheffer believes that the repeated reuse of these themes eventually helped to chip away at Americans' racial prejudices: "Blending the familiar and the strange, the familial and the foreign, these fictions were hugely popular and thoroughly mainstream, reflecting, as well as subtly altering, the affective policies (and politics) of the nation" (9).

Sheffer does acknowledges a cultural reluctance to accept people who fit in the cracks between racial lines, and she insists that the very act of dealing with the issue head-on is what makes the stories she examines so radical. She describes, for example, how Hopkins' Of One Blood combines the tragic mulatto trope with Freudian analysis to build on the incest theme and portray the U.S. "as a national family in denial of its interracial roots and a national psyche in need of integration" (27). Though Hopkins follows in the tradition of black 


\section{Beverly Tomek}

antebellum writers, Sheffer insists that her work is more path breaking than critics have given her credit for. She argues that "where earlier African American novels work within the sentimental tradition to call attention to slavery's destruction of families, with Of One Blood Hopkins expands her critique, calling attention to the psychological consequences of racism and gender discrimination" (31). Along with the other stories, Hopkins' illustrates that "the true threat to the nation was not miscegenation, but rather: (a) the failure to recognize existing interracial family ties and (b) the social hierarchies on which those kinship bonds were based" (16). By pointing this out, these romances "created the imaginative conditions for twentieth-century multiculturalism, with its foundation in the fantasy of the nation as an interracial family" (18).

Mourning Dove's Cogewea: The Half Blood illustrates these themes nicely through the story of a Native American family in the American West that reaches out and accepts a number of European immigrants who eventually marry into the family. Sheffer traces a number of radical innovations in Mourning Dove's work - the open insistence that all Americans are to some degree of mixed blood, the argument that race is socially constructed rather than biological, and the notion that kinship is defined through "shared endeavor" rather than "shared blood" (120). At a time in which the federal government actually encouraged "miscegenation" between whites and Native Americans in an attempt to assimilate the latter and, in some sense, turn them white, Mourning Dove both evokes and criticizes the "myth of the Vanishing Indian" to show that Native Americans remained more than "cultural relics" and would play a key role in the nation's future (120-121). The mixed marriages in the novel serve the opposite end of what the government desired. Instead of the Native American being subsumed by the white partner, both parties retain and share their culture. Thus, Sheffer argues that Mourning Dove creates "an alliance of Native Americans and European immigrants" by creating "an extended multicultural family in the West" (124). Turning official government policy on its head, she makes miscegenation "a kind of canny survival strategy" and develops her own type of assimilation that works for, rather than against, Native American culture. Through Mourning Dove's novel, "the half-breed redefines assimilation," choosing to marry "good European immigrants" who "adapt to the half breed's values" (124). Thus, Sheffer maintains that Mourning Dove changes the focus of discourse from biology to culture. Whatever happens genetically, both cultures will be preserved out of mutual respect. The western ranch where Cogewea and her family live, then, "represents an idealized version of the U.S. nation: the place where a ragtag band of outsiders create a meaningful community" (145). Connections there are forged out of kinship, or a sense of shared purpose, rather than blood or race.

Sheffer's analysis is fascinating and does a nice job of showing how stories that appear on the surface to perpetuate stereotypes actually retell old tales in new ways. The characters in the short stories and novels work together to claim an identity and push for acceptance in the broader culture. Whether the nation 
will accept them or not, they warn that they represent a healthier future, one in which mixture is appreciated rather than hidden, or "colonized," to use Clark's term. Sheffer concludes that these stories "are socially provocative and politically radical, demanding a reckoning with the nation's past in order to chart a more inclusive future" (172). She contends that it was radical of the authors to create such strong mixed-race characters who took such determined action to dictate the paths of their own lives, and she makes a solid case. However, she remains so focused on showcasing the agency of those of mixed race that she tends to overlook the complicated tensions between those of "mixed race" and those who belong to categories of "full-blood" otherness. The stories are radical in that they emphasize heroes and heroines caught between races, but they do not do much to complicate the racial hierarchy of the late-nineteenth-century U.S. beyond that.

In a similar vein, Sheffer could have strengthened her work by giving more historical context about what her authors were up against. The U.S. had a long tradition of absolute hatred of, and virulent opposition to, racial mixing. "Amalgamation" and "miscegenation" stirred violent resistance in the U.S. not just before the Civil War but also in the period about which Sheffer is writing. The book would be stronger with more mention of this cultural context. She gives long overdue agency to characters like Cogewea, but she needs to make clear just what those characters and the writers who created them (especially those who were half black and half white) would have faced as they fought for their rightful place in the nation. The works Sheffer discusses would seem even more important when put into stark contrast with the violence and racism of the time in which they appeared. What this means, in general, is that while her very strong literary analysis adds significantly to the story of racial and ethnic mixing and the role those of "mixed race" played in U.S. literary culture, the analysis needs to go hand in hand with an explanation of the history behind American racial attitudes. Her best chapter, the one on Mourning Dove's stories about the Native American "half-breeds," is the strongest in the book because of the degree to which she sets the historical context, putting Mourning Dove's stories into direct relief against federal Indian policy.

Finally, Sheffer's book offers fascinating literary analysis in most chapters, but the last chapter breaks the coherence by focusing on a museum exhibit in Jane Addams' Hull House. This chapter contains interesting information, but it does not fit with the rest of the book, and it leaves the reader wondering why it was included. If Sheffer had simply wanted to include "new immigrants" in her collection, could she have chosen some of the fiction, or even memoirs, written by members of this community to highlight similar issues of place and belonging? Not only does the chapter break the book's flow because it is the only one not to analyze literature, it also highlights the need for historical context, because the discussion of Progressivism falls a bit flat. Not making a clear enough distinction between progressive, an adjective still in use today to mean forward-looking, and Progressive, a movement that flourished at a specific time 


\section{Beverly Tomek}

in history, Sheffer seems to want the latter to be more enlightened than it was in terms of racial and ethnic issues. She admits in passing that there were limits to the movement's concerns over racism, for example, but what she really would have needed to do for a thorough discussion here was to include a great deal more background information on the movement's racist and nativist elements and then show exactly where Addams was a product of her time and where she transcended her fellow Progressives. She mentions Progressive reformers' efforts to bridge cultural gaps but she neglects to mention that a great many Progressives of the period tended to support segregation as the solution to solving racial tensions. Also, the one Progressive who did the most to fight for African American rights was Ida B. Wells, and her very importance lies in the ubiquity and brutality of lynching, the very act that illustrates the depth of American racism and underscores the challenges faced by those who were even suspected of having crossed the color line. In reality, Sheffer's authors were writing stories that begged for an enlightened future at the same moment that men and women across the Southern U.S. were being brutalized under the guise that they had created, or tried to create, the kind of relationships described in the stories.

Collectively, these two works illustrate how well history and literature can complement each other in getting to the essence of the nation's cultural narrative and in using the realities and the narratives of the past to at least strive to create a better future. As Clark shows, there can be danger in taking the accuracy of fiction for granted, but as both books illustrate, fiction reflects the concerns of the culture in which it is produced. When we combine these two studies, we can arrive at a deeper understanding, both of what actually happened, and of how the people who lived through the times interpreted what happened. As Sheffer demonstrated, we can also see how some worked to shape the world around them and have some influence over what was to come next, whether or not their aspirations were to become reality. Perhaps we can learn from Clark's story of the American quadroon and the writers featured in Sheffer's book and find a way to push forward with the as-yet-unrealized vision of complete equality and help create a genuinely, and unapologetically, multicultural America.

\section{Notes}

1. For a look at the legalities of "miscegenation" in the South, see Julie Novkov, "Racial Constructions: The Legal Regulation of Miscegenation in Alabama, 1890-1934," Law and History Review 20, no. 2 (Summer 2002): 225-77. For the origin of the term "miscegenation" and its use during the Civil War, see Sidney Kaplan, "The Miscegenation Issue in the Election of 1864," Journal of Negro History 34, no. 3 (July 1949): 274-343.

2. For some recent works on the topic, see Tavia Nyong'o, The Amalgamation Waltz: Race, Performance, and the Ruses of Memory (Minneapolis: University of Minnesota Press, 2009); Diana Rebekka Paulin, Imperfect Unions: Staging Miscegenation in U.S. Drama and Fiction (Minneapolis: University of Minnesota Press, 2012); Elise Lemire, "Miscegenation": Making Race in America (Philadelphia: University of Pennsylvania Press, 2002); Werner Sollors, Interracialism: Black-White Intermarriage in American History, Literature, and Law (New York: Oxford University Press, 2000). 